\title{
Article \\ A Digital Tale of Two Cities-Observing the Dynamics of the Artificial Intelligence Ecosystems in Berlin and Sydney
}

\author{
Thorsten Lammers ${ }^{1, * \mathbb{D}}$, Dilek Cetindamar ${ }^{1}\left(\mathbb{B}\right.$ and Maren Borkert ${ }^{2}$ \\ 1 School of Information, Systems and Modelling, University of Technology Sydney, Broadway, \\ Ultimo, NSW 2007, Australia; dilek.ck@uts.edu.au \\ 2 XU Exponential University of Applied Sciences, 14482 Potsdam, Germany; m.borkert@xu-university.de \\ * Correspondence: thorsten.lammers@uts.edu.au
}

check for updates

Citation: Lammers, T.; Cetindamar,

D.; Borkert, M. A Digital Tale of Two Cities-Observing the Dynamics of the Artificial Intelligence Ecosystems in Berlin and Sydney. Sustainability 2021, 13, 10564. https://doi.org/ $10.3390 /$ su131910564

Academic Editor: Fernando Almeida

Received: 5 August 2021

Accepted: 15 September 2021

Published: 23 September 2021

Publisher's Note: MDPI stays neutral with regard to jurisdictional claims in published maps and institutional affiliations.

Copyright: (c) 2021 by the authors. Licensee MDPI, Basel, Switzerland. This article is an open access article distributed under the terms and conditions of the Creative Commons Attribution (CC BY) license (https:// creativecommons.org/licenses/by/ $4.0 /)$.

\begin{abstract}
In entrepreneurial ecosystems (EEs), geographical and contextual factors play a big role in shaping the knowledge bases for digital innovation. While cities around the world compete to be perceived as successful "tech startup hubs", proactive urban strategies are needed to create knowledge spillovers into EEs. This study explores the evolution of artificial intelligence (AI) knowledge practices in the EEs of Berlin and Sydney by using knowledge-spillover theory of entrepreneurship. The study utilizes a bibliometric analysis of secondary data in combination with exploratory stakeholder interviews conducted for both cities. Findings underline the critical role of experimental knowledge in driving the momentum of the EEs and the supporting role of policies imprinting knowledge practices. The paper shows how the dynamics of EEs can be explored empirically and raises awareness of the role of specialised and integrated policies in determining a city's overall success in building EEs.
\end{abstract}

Keywords: artificial intelligence; knowledge-spillover theory of entrepreneurship; entrepreneurial ecosystem; Berlin; Sydney

\section{Introduction}

Entrepreneurial ecosystems (EE) are "a set of interdependent actors and factors coordinated in such a way that they enable productive entrepreneurship within a particular territory" [1]. In EEs, all actors and their relationships influence both the formation of opportunities and their implementations [2,3]. The popularity of EEs comes from a systemic view of entrepreneurship. However, to some degree, literature reviews on EEs point out how studies focus on generic models of entrepreneurial activity while neglecting the role of context [4,5]. Context is mostly considered by employing a proxy or control variables without any more profound analyses of the cultural, social, and economic structures that have a strong influence on the entrepreneurs' action space and their actions [6]. On top of this limitation, scholars have recently argued that digitisation is reducing spatial dependence and that entrepreneurship is becoming much less of a local phenomenon [7]. This study joins the studies opposing this view by considering the local dimension to be crucial for investigating entrepreneurship [8]. Based on this timely discussion, we aim to unfold the practices around knowledge bases in an EE in a given region, choosing the city as an observation area. Regional knowledge bases are the source for opportunities in innovation and entrepreneurship [9]. The starting point for analysis is identifying actors related to knowledge generation and diffusion that are critical elements of EEs in creating opportunities [10]. This identification step necessitates the understanding of knowledge bases and their dynamics at the city level.

This paper is guided by the knowledge-spillover theory of entrepreneurship to understand the dynamics of EEs [10]. This theory argues that EEs result from an unfolding process that emerges in and through the diffusion of knowledge of a diverse set of agencies in a geographically bounded region [11]. 
Knowledge spillovers do not happen automatically [12]. Hence, it is essential to expand the investigation of knowledge bases to determine the role of intervening or supporting actors such as government or universities in the knowledge diffusion process.

Ecosystems provide processes through which entrepreneurs acquire resources, knowledge, and support, increasing their competitive advantage and ability to scale up [13]. Considering the difficulties of understanding complex EEs empirically [8,13], this study takes on the small, knowledge-intensive sub-system of artificial intelligence [AI] that is part of the wider urban EE [14] and provides a detailed analysis for the cities of Berlin and Sydney. AI, being one of the big disruptive technologies, refers to "a system's ability to interpret external data correctly, to learn from such data, and to use those learnings to achieve specific goals and tasks through flexible adaptation" [15]. Being a generalpurpose technology, $\mathrm{AI}$ is expected to heavily influence new venture processes and to have a profound impact on EEs by being a core source of opportunities to tap into [7,16,17].

In sum, this study aims to answer the following question: how does the interrelationship between practices of policies and the AI knowledge bases in Berlin and Sydney EEs evolve? To do so, we use a triangulation of diverse data sets collected for Berlin and Sydney. Regarding the knowledge bases, we adapt our previous study's assessment model and collect data from secondary sources regarding academic output, intellectual property (IP), and startup formation. We observe the evolution of three types of knowledge bases: emerging, realised, and experimental [18]. The findings are summarised with an illustration of the evolution of the key actors and their activities over time to indicate the key strengths and weaknesses both in Berlin and Sydney's AI knowledge among the different bases. Additionally, we analyse relevant policy papers documented by local governments and conduct explorative expert interviews to identify the vision and supporting practices of cities and provide additional insight into the data. By conducting these analytical steps, we aim to generate critical information on the role of context in knowledge-intensive EEs, supporting urban policymakers in their ambition to create frameworks for successful urban startup landscapes.

This paper has six sections. After this introduction, Section 2 introduces a summary of EEs as an unfolding practice and proposes an assessment model to observe the relationships between policy and knowledge located in cities. Section 3 presents the mixed-methodology approach and details the data collected from both secondary and primary sources. Section 4 presents the findings related to the practices of the AI EEs in Berlin and Sydney in a comparative manner. We discuss the findings and their implications on theory and practice in Section 5. The Section 6 concludes the paper by summarising the results, limitations of the paper, and future research suggestions.

\section{Background}

The types of resources available in an EE and their flow within are considered the deciding factors for the EE's strength and ability to function [19]. Even though Spigel and Harrison [19] cluster these resources under three categories (capital, people, and knowledge), they propose to perceive EEs as ongoing processes through which startups and scale-ups gain a competitive edge from their regional environments. Studies increasingly try to focus on ecosystems as processes or practices where ecosystems are not static but rather dynamic and evolve over time [11,19-21].

The need to understand processes in EEs might be addressed by drawing on the knowledge-spillover theory of entrepreneurship [22,23]. This theory increases the importance of one particular actor's influence in a context: policymakers. By examining the creation and spillover of knowledge, the theory points out how firm creation can be regarded as an endogenous process in response to the availability of unused knowledge in a region. Furthermore, a strategic perspective has been added to this theory by arguing that a proactive strategy is needed at a macro level [24].

In the context of geography, there is an ongoing discussion on its importance for EEs. On the one hand, a reduced role of geography is identified primarily due to the ubiquitous 
nature of digital technologies that reduce spatial dependence for entrepreneurs [7]. On the other hand, studies in regional science and entrepreneurship literature indicate a strong impact of regional effects $[25,26]$. As a unit of analysis, the city is widely adopted to understand material attributes of a context [13]. There are numerous studies on city-level entrepreneurial activities $[27,28]$.

The literature on EEs complains about the complexities involved in a diverse set of actors and different analysis levels and a multiplicity of factors in play. Thus, this study aims to reduce complexity by focusing on a smaller but highly relevant sub-system that is part of the wider EE [14,29]. We delineate a sub-system in an EE by choosing AI as the field of knowledge and the city as the unit of geography. The focus on a single domain of technology allows an in-depth assessment of knowledge bases by reducing the complexity to a manageable degree. AI, as a technical expertise domain, represents a source of knowledge-intensive entrepreneurship, meaning that AI has a high degree of innovative knowledge intensity, exploiting innovative opportunities in diverse sectors [20].

By focusing on AI and city, the paper allows us to elaborate on the digital entrepreneurial ecosystem concept, which integrates the focal areas of the digital ecosystem and entrepreneurial ecosystem by exploring the impact of policy practices on urban economic development [30]. This delineation helps us include nuanced observations to understand cities' digital technology capacities and their potential impact on the city-level entrepreneurial ecosystems.

For our study, we picked two cities to dive into empirically: Berlin and Sydney. Even though they are geographically very far from each other, these two cities are located in economically advanced countries and are regarded as major entrepreneurial hubs in their countries according to international rankings. On a country level, as shown in Table 1, Australia ranks higher than Germany on the overall health of the EE as captured by the Global Entrepreneurship Index, which combines a range of data on aspects of a country's social and economic infrastructures with entrepreneurial attitudes of the population. Both countries' positions remain relatively stable over time. On a city level however, some more significant moves can be observed. According to the Global Startup Ecosystem Reports [31,32], which compares the competitiveness of the world's biggest urban EEs across categories including performance, funding, connectedness, market reach, knowledge, talent, and growth of ecosystem, Berlin performs better than Sydney and has improved its position since 2012. Sydney's entrepreneurial performance has been deteriorating in the same period since 2012. This is why analysing these two cities could allow us to enrich our understanding of how context affects the utilisation of knowledge bases in EEs by conducting a comparative analysis.

Table 1. Rankings of Germany, Australia, Berlin, and Sydney in Entrepreneurship Indices.

\begin{tabular}{cccccccc}
\hline \multicolumn{2}{c}{ Berlin } & \multicolumn{2}{c}{ Germany } & \multicolumn{2}{c}{ Sydney } & \multicolumn{2}{c}{ Australia } \\
\hline $\mathbf{2 0 1 2}$ & $\mathbf{2 0 1 9}$ & $\mathbf{2 0 1 1}$ & $\mathbf{2 0 1 9}$ & $\mathbf{2 0 1 2}$ & $\mathbf{2 0 1 9}$ & $\mathbf{2 0 1 1}$ & $\mathbf{2 0 1 9}$ \\
\hline $15 / 20$ & $10 / 54$ & $14 / 55$ & $15 / 137$ & $12 / 20$ & $23 / 54$ & $6 / 55$ & $6 / 137$ \\
\hline
\end{tabular}

Sources: Country-level data from the Global Entrepreneurship Index 2011 [33] and 2019 [34] and city-level data from the Global Startup Ecosystem Report 2012 [31] and 2019 [32].

In sum, we argue that the assessment of technical knowledge bases could provide a good picture of the overall knowledge dynamics in a region. To complement this analysis, we also offer the observation of local policies instrumental in shaping EEs where these knowledge bases evolve. Only then can the dynamics of a knowledge-intensive EE become evident.

\section{Materials and Methods}

Our research applies a mixed-method research design that combines bibliometric analysis of secondary data with document analysis and qualitative interviews. The use of multiple data sources can ensure the reliability of the study findings and reduce bias [35]. 
Qualitative methods facilitate investigation of how people place meanings on a particular phenomenon, process, structure, or setting [36]. Since qualitative methods allow researchers to capture rich nuances of responses beyond surveys, they are widely used to obtain rich data [37]. Figure 1 provides an overview of the research framework adopted and its key elements. The applied mixed-method research design is used to analyse the AI practices regarding the (1) knowledge bases and (2) policies in Berlin's and Sydney's EE.

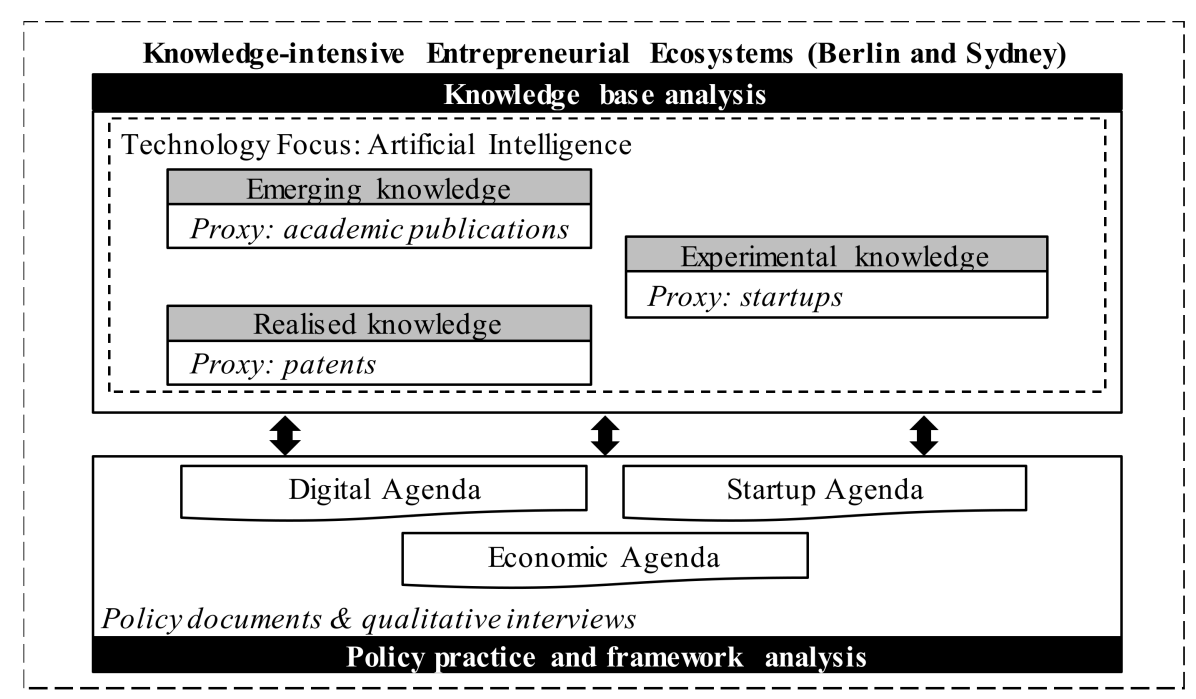

Figure 1. Research framework.

Our research sits at the nexus of both the knowledge bases for AI technology, and the related policy frameworks of the knowledge-intensive EE. Following the assessment model developed earlier [18], this paper focuses on the three key knowledge bases to observe the evolution of AI-based EEs: emerging, realised, and experimental. Each knowledge base resides on a key ecosystem agent, namely researchers, inventors, and entrepreneurs. To expand this model, we argue for including one new assessment: policy practices developed by local authorities that set the vision and shape the supporting mechanisms for these three key actors of EEs.

\subsection{Analysis of Knowledge Bases}

We analyse the knowledge bases of AI technology in both cities. To do this, we use a bibliometric analysis of secondary data. Academic publications serve as a proxy for the emerging knowledge, patents as a proxy for realised knowledge, and startup data as a proxy for experimental knowledge [18]. In other words, these three actors' practices are captured through their actions regarding publications, patents, and entrepreneurial activities [38-41].

\subsubsection{Emerging Knowledge: Publications}

For the analysis of academic publications in the field of AI, we used the Web of Science Core Collection as a data source. As the world's leading citation index for scientific and scholarly research, the Web of Science is widely used for bibliometric analyses of academic publications [42]. We used the subject categories [43]. The Web of Science features exactly one category about AI, namely "Computer Science, Artificial Intelligence." Following Gao et al. [44], articles belonging to this subject category were used as a basis for our search. Table 2 summarises our search strategy, including the focus on city and timespan. We also ran a comparative country-based analysis for Germany and Australia as a whole by removing the city-specific field (CI) from the search string below. 
Table 2. Search strategy for publications.

\begin{tabular}{|c|c|c|}
\hline Field & Description & Value \\
\hline WC & WoS Category & (Computer Science, Artificial Intelligence) \\
\hline \multicolumn{3}{|r|}{ Boolean AND } \\
\hline $\mathrm{CI}$ & City & (Berlin) or (Sydney) \\
\hline \multicolumn{3}{|r|}{ Boolean AND } \\
\hline $\mathrm{CU}$ & Country/Region & (Germany) or (Australia) \\
\hline \multicolumn{3}{|r|}{ Boolean AND } \\
\hline DT & Document Type & $\begin{array}{l}\text { (Article) "Reports of research on original works. Includes } \\
\text { research papers, features, brief communications, case reports, } \\
\text { technical notes, chronology, and full papers that were published } \\
\text { in a journal and/or presented at a symposium or conference." }\end{array}$ \\
\hline \multicolumn{3}{|r|}{ Further filters } \\
\hline & Timespan & $2000-2019$ \\
\hline & Indexes & $\begin{array}{l}\text { SCI-EXPANDED, SSCI, A\&HCI, CPCI-S, CPCI-SSH, ESCI, CCR - } \\
\text { EXPANDED }\end{array}$ \\
\hline
\end{tabular}

\subsubsection{Realised Knowledge: Patents}

For the analysis of AI-related patents, we used the Patentscope database, which is run by the World Intellectual Property Organization. The database contains patent applications under the Patent Cooperation Treaty, patent documents from participating regional patent offices, and patent documents from many national patent collections [45]. For the search, we used a set of Cooperative Patent Classification [CPC] codes on AI, which was identified for the Patentscope Artificial Intelligence Index as being adequate to be used independently without using keywords [46]. A code-based approach can help overcome some limits of keyword-based approaches given the size of the technological field and the not always explicitly named relationship of a patent to the field [47]. We specified the search to the required timeframe of 2000-2019 and the cities of Berlin and Sydney using field codes as outlined in Table 3. We also ran a comparative country-based analysis for Germany and Australia as a whole by removing the city-specific field (AAD) from the below search string.

\subsubsection{Experimental Knowledge: Startups}

For the analysis of AI-related startups in both cities, we used Crunchbase as a data source. Crunchbase is a commercial database on innovative companies and has already been widely used by scholars to describe startup ecosystems from different angles [48]. We followed Crunchbase's search query on AI startups [49]. We refined the search by filtering to the required timeframe of 2000-2019 and the cities of Berlin or Sydney. We also ran a comparative country-based analysis for Germany and Australia. The search strategy is summarised Table 4. 
Table 3. Search strategy for patents.

\begin{tabular}{|c|c|c|}
\hline Field & Description & Value \\
\hline DP & Publication Date & 2000 to 2019 \\
\hline \multicolumn{3}{|r|}{ Boolean AND } \\
\hline $\mathrm{AAD}$ & $\begin{array}{l}\text { Applicant } \\
\text { Address }\end{array}$ & Berlin/Sydney \\
\hline \multicolumn{3}{|r|}{ Boolean AND } \\
\hline AADC & $\begin{array}{c}\text { Applicant } \\
\text { Address } \\
\text { Country }\end{array}$ & DE/AU \\
\hline \multicolumn{3}{|r|}{ Boolean AND } \\
\hline $\mathrm{CPC}$ & $\begin{array}{l}\text { Cooperative } \\
\text { Patent } \\
\text { Classification }\end{array}$ & $\begin{array}{c}\text { (A61B5/7264 OR A61B5/7267 OR A63F13/67 OR B23K31/006 OR } \\
\text { B25J9/161 OR B29C2945/76979 OR B29C66/965 OR } \\
\text { B60G2600/1876 OR B60G2600/1878 OR B60G2600/1879 OR } \\
\text { B60W30/06 OR B60W30/10 OR B60W30/14 OR B62D15/0285 OR } \\
\text { B64G2001/247 OR E21B2041/0028 OR F02D41/1405 OR } \\
\text { F03D7/046 OR F05B2270/707 OR F05B2270/709 OR } \\
\text { F05D2270/709 OR F16H2061/0081 OR F16H2061/0084 OR } \\
\text { G01N2201/1296 OR G01N29/4481 OR G01N33/0034 OR } \\
\text { G01R31/2846 OR G01R31/3651 OR G01S7/417 OR G05B13/027 } \\
\text { OR G05B13/0275 OR G05B13/028 OR G05B13/0285 OR } \\
\text { G05B13/029 OR G05B13/0295 OR G05B2219/33002 OR } \\
\text { G05D1/00 OR G05D1/0088 OR G06F11/1476 OR G06F11/2257 } \\
\text { OR G06F11/2263 OR G06F15/18 OR G06F17/16 OR G06F17/2282 } \\
\text { OR G06F17/27 OR G06F17/28 OR G06F17/30029 OR } \\
\text { G06F17/30247 OR G06F17/30401 OR G06F17/3043 OR } \\
\text { G06F17/30522 OR G06F17/30654 OR G06F17/30663 OR } \\
\text { G06F17/30666 OR G06F17/30669 OR G06F17/30672 OR } \\
\text { G06F17/30684 OR G06F17/30687 OR G06F17/3069 OR } \\
\text { G06F17/30702 OR G06F17/30705 OR G06F17/30731 OR } \\
\text { G06F17/30743 OR G06F17/30784 OR G06F19/24 OR G06F19/707 } \\
\text { OR G06F2207/4824 OR G06K7/1482 OR G06K9/00 OR } \\
\text { G06N3/00 OR G06N3/004 OR G06N5/003 OR G06N7/005 OR } \\
\text { G06N7/046 OR G06N99/005 OR G06T2207/20081 OR } \\
\text { G06T2207/20084 OR G06T2207/20084 OR G06T2207/30236 OR } \\
\text { G06T2207/30248 OR G06T3/4046 OR G06T9/002 OR G08B29/186 } \\
\text { OR G10H2250/151 OR G10H2250/311 OR G10K2210/3024 OR } \\
\text { G10K2210/3038 OR G10L15/00 OR G10L17/00 OR G10L25/30 } \\
\text { OR G11B20/10518 OR H01J2237/30427 OR H01M8/04992 OR } \\
\text { H02H1/0092 OR H02P21/0014 OR H02P23/0018 OR } \\
\text { H03H2017/0208 OR H03H2222/04 OR H04L2012/5686 OR } \\
\text { H04L2025/03464 OR H04L2025/03554 OR H04L25/0254 OR } \\
\text { H04L25/03165 OR H04L41/16 OR H04L45/08 OR H04N21/4662 } \\
\text { OR H04N21/4666 OR H04Q2213/054 OR H04Q2213/13343 OR } \\
\text { H04Q2213/343 OR H04R25/507 OR Y10S128/924 OR } \\
\text { Y10S128/925 OR Y10S706/00) } \\
\end{array}$ \\
\hline
\end{tabular}


Table 4. Search strategy for startups.

\begin{tabular}{ccc}
\hline Field & Operator & Value \\
\hline Funding Status & includes any & "Seed," “Early Stage Venture," “Late Stage Venture" \\
\hline Industries & includes any & "Artificial Intelligence" \\
\hline Operating Status & equals & "Active" \\
\hline Founded Date & between & "2000" and "2019" \\
\hline Headquarters Location & includes any & "Berlin" or "Sydney" or "Germany" or "Australia" \\
\hline
\end{tabular}

\subsection{Analysis of EE Policy Practices}

We analyse the two cities' ecosystems' policy practices to understand the role and level of political influence on this knowledge landscape. We follow the lead of recent studies on policies and the state's role by using two data sources as proxy measures to reflect ongoing intervening policy-based practices of local authorities [50,51]. We analyse policy documents from both cities related to three focus areas: digital technology, the knowledge-intensive EE, and the regional economic development. Additionally, we conduct interviews with experts on the three focal areas of both cities to complement the analysed secondary data. The aim was to help us overcome silos by understanding the interactions between knowledge sources and exploring their interrelated dynamics. Therefore, we identified individuals in both cities who could speak about the urban tech startup scenes from a holistic perspective. They were able to identify and interpret possible connections and relations between the knowledge sources and connect them to policy-making and economic development in their city, allowing them to explore a new expert-based observational perspective on the existing data [52].

\subsubsection{Policy Documents}

For both cities, we identified the three policy documents that best aligned with the focus areas and described the cities' policy agendas in those areas (see Table 5). Considering its supplementary role in our mixed-method approach, we analysed the document using a twofold iterative approach. We utilised a thematic analysis to recognise patterns and emerging themes relevant to our research question [53]. Additionally, we applied the codes identified in the interviews to integrate the data with our other findings [54].

Table 5. Overview of analysed policy documents.

\begin{tabular}{ccc}
\hline & \multicolumn{2}{c}{ Berlin } \\
\hline Focus Area & Document Title/Code & Reference \\
\hline EE & Startup Agenda/BD1 & {$[55]$} \\
\hline Digital Technology & Digital Economy in Berlin/BD2 & {$[56]$} \\
\hline Economic Development & Industrial City Berlin Masterplan 2018-2021/BD3 & {$[57]$} \\
\hline Focus Area & Sydney & Reference \\
\hline EE & Document Title/Code & {$[58]$} \\
\hline Digital Technology & Tech Startups Action Plan/SD1 & {$[59]$} \\
\hline Economic Development & Digital Strategy/SD2 & {$[60]$} \\
\hline
\end{tabular}

\subsubsection{Interviews}

For the explorative interviews, we chose a semi-structured design around themes, which were developed concerning the research purpose [61]. While we offered the respondents flexibility to steer the interview in the most meaningful direction, we focused on the impacts of the urban environment and digital technology landscape. This approach allowed for maintaining a logical flow of the interview, general comparability of the results, and ultimately identifying critical factors in the urban EE [62]. The guiding themes during the interviews evolved around a description of unique characteristics of the city's 
knowledge-intensive EE, its dynamics and historical evolution, the role of technologyspecific knowledge bases for its success, the role of policy and government actions as contributing or inhibiting factors, and the EE's contribution to the city's broader success in economic development.

To complement the collected secondary data in the best possible way, we identified the right respondents by identifying a set of criteria for selection [62]. For this, we followed a purposive sampling approach, which involves "identification and selection of individuals or groups of individuals that are proficient and well-informed with a phenomenon of interest" [63]. Based on the above-outlined themes and our focal areas, the criteria were selected to be (a) strong knowledge of the city and its history and dynamics concerning the EE and (b) as per the role description, a deep level of expertise in at least two of the three focus areas. Exploratory studies need to ensure a wide range of organisations from different sectors are covered to prevent overrepresentation of one particular sector. This inclusivity concern is especially genuine for small samples such as in this study. Thus, the participating experts for both Berlin and Sydney in this study were chosen to reflect government, public institutions, and the private sector. Table 6 shows an overview of the interviewees and their expertise in relation to our research methodology's three focus areas.

Table 6. Overview of interviewee sample.

\begin{tabular}{|c|c|c|c|c|c|c|}
\hline Code & Role & Perspective & Organisation & \multicolumn{3}{|c|}{ Focus Area } \\
\hline & & & & EE $^{1}$ & DT $^{2}$ & ED $^{3}$ \\
\hline \multicolumn{7}{|c|}{ Berlin } \\
\hline B1 & Manager & Urban Startup Affairs & City Government & $x$ & & $x$ \\
\hline B2 & Founder & Digital Policy Making & Think Tank & & $x$ & $x$ \\
\hline B3 & Speaker & Urban Digitalisation & $\begin{array}{l}\text { Research } \\
\text { Institution }\end{array}$ & $\mathrm{x}$ & $x$ & $\mathrm{x}$ \\
\hline B4 & $\begin{array}{l}\text { Founder and } \\
\text { Director }\end{array}$ & Digital Society & $\begin{array}{l}\text { Research } \\
\text { Institution }\end{array}$ & $\mathrm{x}$ & $x$ & \\
\hline \multicolumn{7}{|c|}{ Sydney } \\
\hline S1 & Manager & Economic Programs & City Government & $x$ & & $x$ \\
\hline S2 & Deputy CEO & City Competitiveness & Think Tank & $x$ & & $x$ \\
\hline S3 & Director & Entrepreneurship & $\begin{array}{l}\text { Research } \\
\text { Institution }\end{array}$ & $\mathrm{x}$ & $\mathrm{X}$ & \\
\hline S4 & Executive Director & $\begin{array}{c}\text { Innovation and } \\
\text { Entrepreneurship }\end{array}$ & $\begin{array}{l}\text { Research } \\
\text { Institution }\end{array}$ & $\mathrm{x}$ & $x$ & $\mathrm{x}$ \\
\hline
\end{tabular}

Note: ${ }^{1}$, Entrepreneurial Ecosystem; ${ }^{2}$, Digital Technologies; ${ }^{3}$, Economic Development.

Overall, we conducted eight semi-structured interviews. To ensure reliability, several authors conducted interviews. Interviews were held between February and March 2019 and lasted for about $45 \mathrm{~min}$. They were recorded, transcribed, and coded using standard processes and software. The authors held frequent discussions and collaborated on the transcription and coding processes to create an overlap between data collection and data analysis.

\section{Results}

In this section, we describe the results of our analysis. First, we present the findings from the bibliometric analysis of the knowledge bases, followed by the policy framework analysis.

\subsection{Knowledge Dynamics}

Table 7 provides a first overview of the results from the two cities' knowledge base analysis within their national contexts. 
Table 7. Overall comparison of search result totals.

\begin{tabular}{ccccccc}
\hline & Berlin & Germany & Ratio [\%] & Sydney & Australia & Ratio [\%] \\
\hline Publications & 914 & 11,018 & 8.3 & 1914 & 8330 & 23.0 \\
\hline Patents & 20 & 1515 & 1.3 & 17 & 159 & 10.7 \\
\hline Startups & 70 & 148 & 47.3 & 29 & 68 & 42.6 \\
\hline Population $^{1}$ & $3,769,495$ & $83,166,711$ & 4.5 & $5,312,163$ & $25,764,100$ & 20.6 \\
\hline
\end{tabular}

Note: ${ }^{1}$ Source is the Wikipedia articles for Berlin, Germany, Sydney, Australia (accessed on 12 June 2020).

On this level, the relative populations are taken into account, which allows us to derive some interesting observations. As both cities host several big research institutions, it is not surprising that they are responsible for a disproportionately high output of AI-related publications compared to the national population-based average. While this effect is more potent in Berlin, it is interesting to note that Sydney's output is a lot bigger than Berlin's in absolute and relative terms. The countries' and cities' performance flips when it comes to patents. Here Germany, as well as Berlin, outperforms Australia/Sydney. However, both cities are underrepresented in patent output, which leads to the assumption that IP (as opposed to publications) is generated mostly in big companies, which are not located in capital cities. For startup numbers, both cities are heavily overrepresented in their respective national contexts. The qualities of big cities seem to be an attraction factor for startup ecosystems. It is also interesting to note that Berlin not only outperforms Sydney, but also hosts more AI startups than Australia as a whole.

Figures 2 and 3 show the AI knowledge dynamics of Berlin and Sydney. The clear drop in publication output in both cities in the mid-2000s aligns with the perception of a low point of AI research-an "AI winter"-due to hyped up expectations during that time [64]. After that, Sydney seems to enter into an "AI spring", commencing a phase of fast growth [65]. Looking at the number of startups over time, both cities show similar patterns with higher absolute numbers in Berlin. Sydney's case shows some correlation between startups and publications, except for the last two years when publications continue to increase, but startup numbers do not. Last, both cities show a recent decline in founded startups. The relatively low overall numbers for patents also follow the AI winter pattern in the mid-2000s.

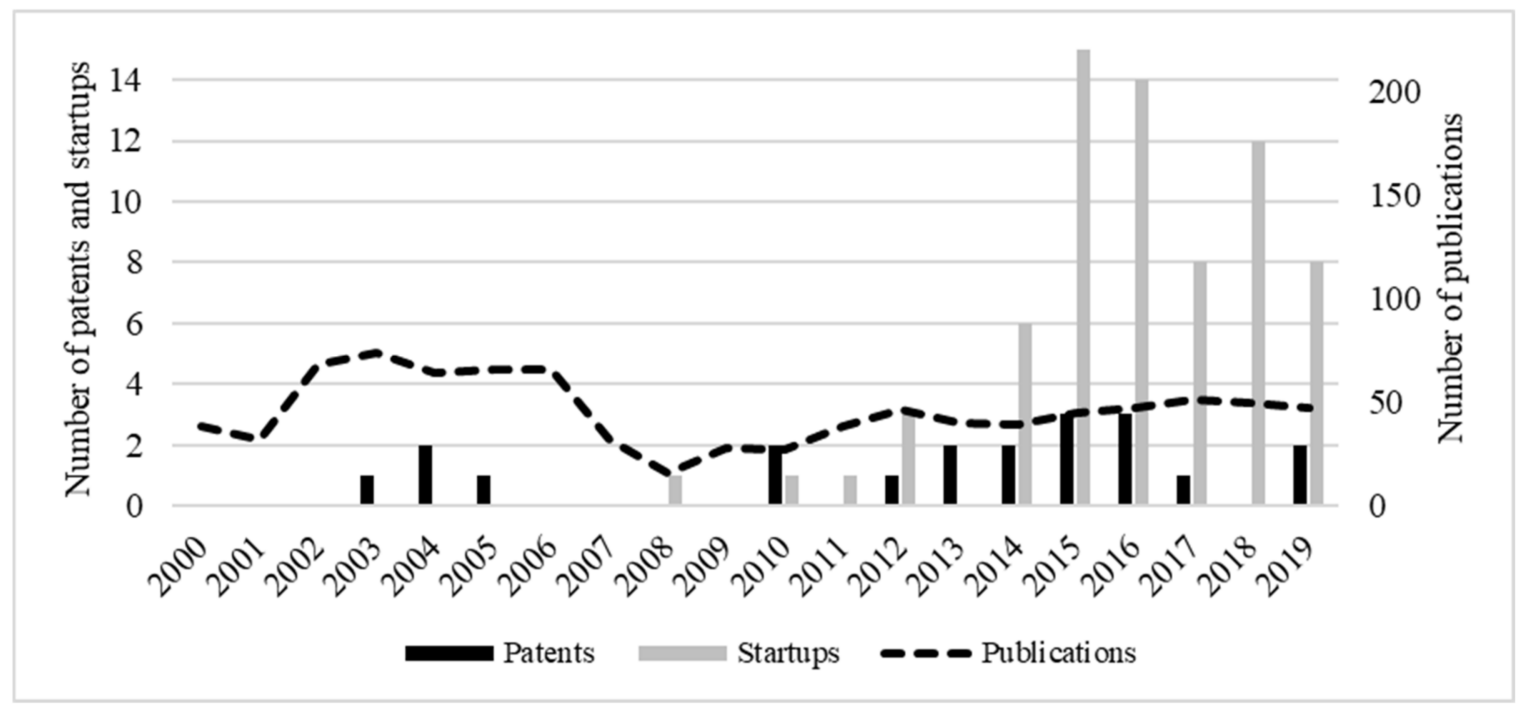

Figure 2. AI knowledge dynamics-Berlin. 


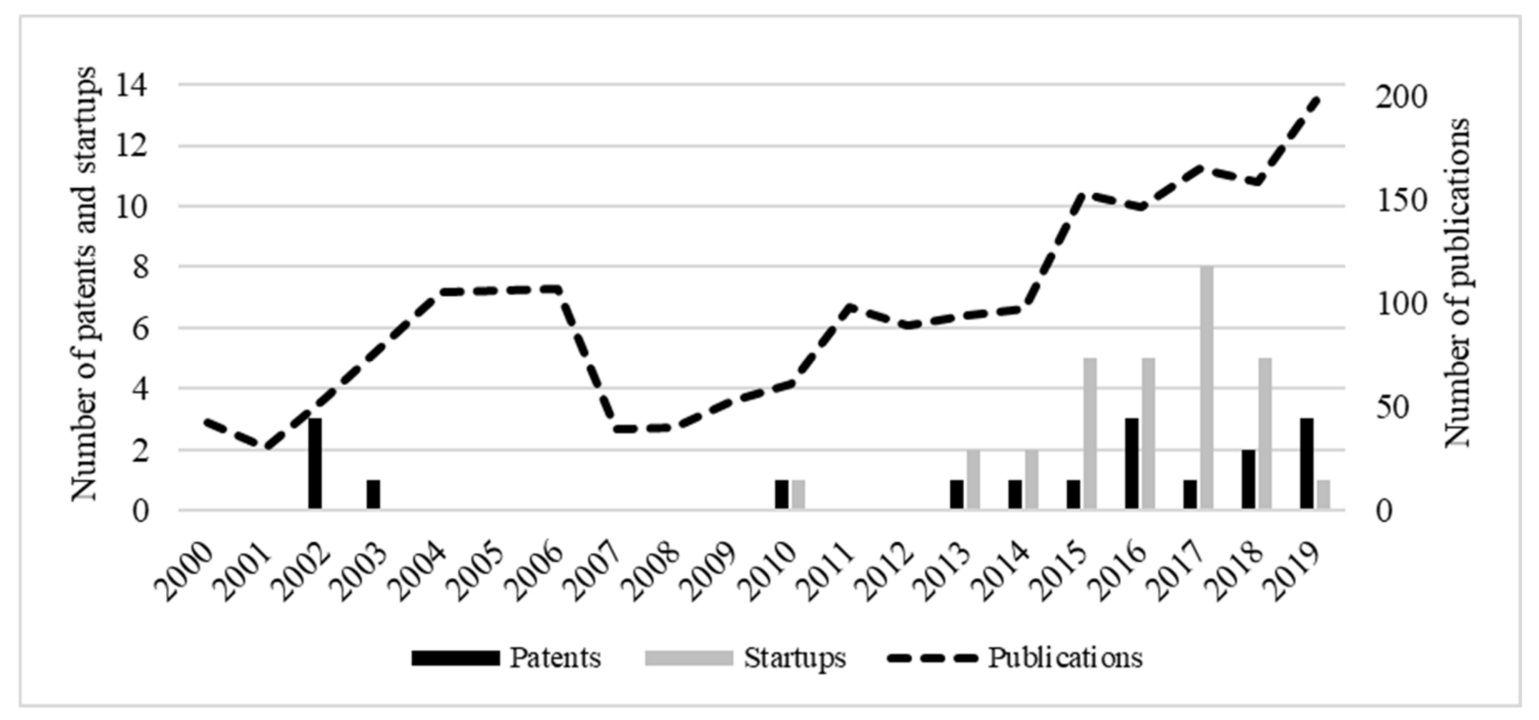

Figure 3. AI knowledge dynamics-Sydney.

Having a closer look at the academic AI outputs, we can identify the strongest collaborating countries for Berlin and Sydney publications. Overall, Sydney shows a much stronger pattern of international collaboration than Berlin. Specifically, China and the USA are worth mentioning, connected to $36 \%$ and $13 \%$ of publications in Sydney, respectively. For Berlin, there is no one country from which authors have collaborated on more than $10 \%$ of publications. The highest collaboration in Berlin seems to take place with American co-authors, representing $9.7 \%$ of publications.

Based on our bibliometric analysis, we can provide a detailed overview of funding bodies supporting publications in both cities (Table 8). The results reveal some interesting connections. While funding of AI-related research form Berlin is mostly connected to funding from home (Germany and the EU), the most significant funding body of research from Sydney comes from China (with six out of the TOP10 funding bodies from China having a share of $36 \%$ ). More funding seems to come from Chinese than from Australian bodies.

While strong international networks are generally seen as favourable, collaboration and foreign funding at this level might lead to the assumption of IP being generated in Sydney but not necessarily being commercialised there. The stronger domestic focus in Berlin might explain the lower numbers of overall output and be interpreted as an enabler for more local knowledge spillovers.

Additionally, universities are the backbone of research output. They hold the TOP3 positions in both cities, contributing to a publication share of $74 \%$ in Berlin and $93 \%$ in Sydney alone. A strong university sector seems to be a prerequisite for knowledge generation.

A final observation can be made about the size distribution of startups in both cities. While almost $60 \%$ of Sydney's startups employ less than 10 employees, this ratio is $47 \%$ in Berlin. However, more strikingly, Sydney has no startups employing more than 100 employees; in Berlin, $6.3 \%$ of startups have more than 100 employees. Adding to the finding that the overall number of startups is significantly higher in Berlin, there is also a noticeable shift towards more prominent organisations. These data indicate a change in the state of the EE, in which some startups have left the early stages of their development. This evolution might increase a "critical mass" effect in the city, becoming an attraction point for other startups and contributing to the EE's organic growth. 
Table 8. Top Funding bodies.

\begin{tabular}{|c|c|c|c|c|c|}
\hline \multicolumn{3}{|l|}{ Berlin } & \multicolumn{3}{|l|}{ Sydney } \\
\hline Funding Body & $\#$ & $\%$ & Funding Body & $\#$ & $\%$ \\
\hline $\begin{array}{l}\text { German Research Foundation } \\
\text { (DFG) }\end{array}$ & 114 & 12.47 & $\begin{array}{l}\text { National Natural Science } \\
\text { Foundation of China }\end{array}$ & 434 & 22.68 \\
\hline $\begin{array}{c}\text { Federal Ministry of Education } \\
\text { Research (BMBF) }\end{array}$ & 47 & 5.14 & Australian Research Council & 426 & 22.26 \\
\hline European Union (EU) & 26 & 2.85 & $\begin{array}{l}\text { National Basic Research } \\
\text { Program of China }\end{array}$ & 84 & 4.39 \\
\hline $\begin{array}{l}\text { National Natural Science } \\
\text { Foundation of China }\end{array}$ & 26 & 2.85 & $\begin{array}{l}\text { Fundamental Research Funds } \\
\text { for the Central Universities }\end{array}$ & 78 & 4.08 \\
\hline $\begin{array}{l}\text { Alexander von Humboldt } \\
\text { Foundation }\end{array}$ & 24 & 2.63 & Australian Government & 51 & 2.67 \\
\hline Austrian Science Fund (FWF) & 14 & 1.53 & $\begin{array}{c}\text { China Postdoctoral Science } \\
\text { Foundation }\end{array}$ & 43 & 2.25 \\
\hline \multirow[t]{4}{*}{ European Community (EC) } & 14 & 1.53 & $\begin{array}{l}\text { National Science Foundation } \\
\text { (NSF) }\end{array}$ & 40 & 2.09 \\
\hline & & & $\begin{array}{l}\text { Foundation Arc pour la } \\
\text { Recherche sur le Cancer }\end{array}$ & 35 & 1.83 \\
\hline & & & China Scholarship Council & 30 & 1.57 \\
\hline & & & $\begin{array}{l}\text { Hong Kong Research Grants } \\
\text { Council }\end{array}$ & 29 & 1.52 \\
\hline
\end{tabular}

Note: Total number and percentage of the publications involved in above 1.5.

\subsection{Policy Practices Related to EE}

This section aligns with the discussions on treating EEs as relationships and spatially bounded localised narratives [13,66,67]. By analysing the narratives from actors in local EEs, two essential practices seem to help us understand how the AI-based EEs are evolving in Berlin and Sydney: prioritising a smart city agenda and offering resources for EEs. We summarise our findings from the interviews and government documents in Tables 9 and 10.

Table 9. The role of government through the lens of policy documents and EE members.

\begin{tabular}{ccc}
\hline Aspect & Policy Document & Interview Statements \\
\hline $\begin{array}{c}\text { Smart city } \\
\text { initiatives }\end{array}$ & $\begin{array}{c}\text { We want Sydney to be a 'smart city'-but } \\
\text { smart cities are not smart just because of } \\
\text { technology-they have smart governance } \\
\text { and empowered communities sharing } \\
\text { knowledge and intelligence about their city. } \\
\text { (SD2) }\end{array}$ & $\begin{array}{c}\text { The smart city initiative in Berlin is more bottom-up and } \\
\text { organic. It is based on mobility technologies. (B1 and B4) } \\
\text { The government supports the smart city initiative in order to } \\
\text { support innovation, especially around waste management or } \\
\text { energy efficiency. (S4) }\end{array}$ \\
$\begin{array}{c}\text { Government } \\
\text { tasks }\end{array}$ & $\begin{array}{c}\text { The main tasks are infrastructure (such as } \\
\text { online city transactions), awareness, } \\
\text { education, city communication, regulations. } \\
\text { (SD3) (BD2) }\end{array}$ & $\begin{array}{c}\text { The city government supports campus startups and hubs. (B1) } \\
\text { role in developing the startup scene. The establishment of } \\
\text { Sydney Startup Hub is an example. (S2) }\end{array}$ \\
\hline $\begin{array}{c}\text { Connection of } \\
\text { digital strategy } \\
\text { with EE strategy }\end{array}$ & (No strong connection between digital and \\
EE policies.) & $\begin{array}{c}\text { A strong connection in urban policy between tech startup } \\
\text { policy and digital development is seen as a success factor in } \\
\text { both cities, but not achieved yet. (S2 and B1) }\end{array}$ \\
\hline
\end{tabular}


Table 10. The key city offerings through the lens of policy documents and EE members.

\begin{tabular}{|c|c|c|}
\hline Aspect & Policy Document & Interview Statements \\
\hline $\begin{array}{l}\text { Human } \\
\text { capital }\end{array}$ & $\begin{array}{l}\text { Berlin offers digital companies unique conditions that are } \\
\text { not found anywhere else in the world: highly skilled } \\
\text { professionals. (BD3) } \\
\text { The city of Sydney has to ensure residents and businesses } \\
\text { having the skills and infrastructure needed to participate } \\
\text { fully in the digital world. (SD2) (SD3) }\end{array}$ & $\begin{array}{l}\text { Human capital is a significant advantage for Berlin. } \\
\text { It attracts talent because people feel well and the } \\
\text { quality of life in the city leads to attract tech startups. } \\
\text { (B2 and B3) } \\
\text { Startups are pushed by the university sector in } \\
\text { Sydney. (S2) }\end{array}$ \\
\hline $\begin{array}{l}\text { Local } \\
\text { knowledge } \\
\text { spillovers }\end{array}$ & $\begin{array}{l}\text { The connection between startups and industry is a } \\
\text { strategic priority. (BD3) } \\
\text { The action item for the government is effectively } \\
\text { facilitating partnerships to maximise benefits. (SD2) }\end{array}$ & $\begin{array}{l}\text { The lack of a corporate landscape in the city is a } \\
\text { challenge. There are silos between academia and } \\
\text { startups. (B2) } \\
\text { A challenge in Sydney is the lack of corporate R\&D } \\
\text { and a focus on the sales market. (S4) }\end{array}$ \\
\hline $\begin{array}{c}\text { Funding } \\
\text { availability }\end{array}$ & $\begin{array}{l}\text { Berlin is the European leader when it comes to VC } \\
\text { investments. (BD2) } \\
\text { Support technology entrepreneurs' access to funding. } \\
\text { (SD1) }\end{array}$ & $\begin{array}{l}\text { The availability of grants or VC money is not a factor } \\
\text { for people or come to Berlin. (B4) } \\
\text { The availability of funding in Sydney is an attraction } \\
\text { for startups. (S2) }\end{array}$ \\
\hline $\begin{array}{c}\text { Data } \\
\text { availability }\end{array}$ & $\begin{array}{l}\text { A robust and comprehensive network in Berlin ensures } \\
\text { seamless internet communication } \\
\text { across all channels. (BD2) } \\
\text { The government should control activities associated with } \\
\text { city data collection, management, use, and release. (SD2) }\end{array}$ & $\begin{array}{c}\text { By making city-related datasets available to startups, } \\
\text { the city can play a huge role in their success. (B1) } \\
\text { The city can act as a pilot customer for startup } \\
\text { outputs. (B1) (S1) }\end{array}$ \\
\hline Quality of life & $\begin{array}{l}\text { Berlin is a relatively young startup space, but now in line } \\
\text { with NY, Tel Aviv, and London. } \\
\text { The startup scene has become a deciding and } \\
\text { image-building economic factor. (BD1) } \\
\text { To attract talent and to nurture the talents of those who } \\
\text { already live in our local area, we need well-managed } \\
\text { urban environments with vibrant neighbourhoods, } \\
\text { high-quality digital infrastructure, and precincts that } \\
\text { attract clusters of talent to live and work. (SD2) }\end{array}$ & $\begin{array}{l}\text { Berlin's attractiveness and living conditions for } \\
\text { young entrepreneurs seem to be its biggest draw } \\
\text { card. Berlin is cool (tolerance, openness) and } \\
\text { relatively cheap to live in. (B1 and B2) } \\
\text { Sydney's lifestyle is high but can be perceived as } \\
\text { detrimental to startup culture. The city is also costly. } \\
\text { (S1 and S2) }\end{array}$ \\
\hline
\end{tabular}

\subsubsection{Drivers of City Policies: The "Smart City" Agenda}

Table 9 summarises some findings from our document analysis and interviews. Local governments perceive that their major tasks cover infrastructure [such as online city transactions], awareness, education, city communication, and regulations. Interestingly, both cities perceive becoming a "smart city" as an enabler and moving force for developing the tech-startup scenes.

The analysis of policy documents points out multiple benefits of having a smart city agenda at the city level. First, the local government becomes a customer, attracting startups to develop innovations for its needs. Second, the local government invests in infrastructure for data communication, improving conditions for digital startups. The local government commits itself to building city-level databases that become a good source of input for startups. Third, local government induces regulations such as data security and ethics that help develop a safe work environment for startups. Fourth, a smart city is a famous catchphrase to attract the city's talent and build a popular brand name.

Giving priority to a "smart city" agenda might, however, cause two unexpected outcomes. First, the local government's focus on public services shapes the innovation direction in the city. Our findings indicate that the top three startup industries in Berlin and Sydney are the same: IT, software, and machine learning. For example, the City of Sydney document puts forward an objective of the smart city as "simpler, clearer, faster and more humane public services" (SD2). According to the interviewee S2, the strong connection of Sydney's EE to the government as its customer results in less disruptive technologies: for example, the Internet of Things, which is a proven technology and demanded by 
government customers such as the transportation agency. In Berlin, B1 points out that mobility technologies heavily determine the Berlin startup scene.

Second, being a smart city might dilute concentrated efforts in EEs. The local government in Sydney assumes that the Digital Strategy and the Tech Startups Action Plan will send positive signals towards talented and innovative people to settle in Sydney (SD2 and SD3). However, these plans do not have any specific focus, such as blockchain or AI, but instead emphasise building a smart city. This is why the plans might fail to have an articulated and integrated action plan that could deliver an ecosystem's specific technological needs.

The involvement of city policies is one critical difference between Berlin and Sydney. In Sydney, the government plays a significant role in developing a startup community. This role is called a top-down approach by S2. On the other hand, in Berlin, the development of startup companies is considered more of an organic process (B1).

\subsubsection{Offering Resources for $\mathrm{EE}$}

Table 10 groups the resources a city could offer regarding the establishment and growth of startups at the city level under five categories: human capital, local knowledge spillovers, funding availability, data availability, and quality of life. These resources look similar to many requirements discussed in the literature of creative and innovative cities [68].

The Economic Development Strategy document (SD3) targets strengthening industry clusters in Sydney. For example, the document reads: "The City will seek to encourage innovation by continuing to build on and enhance the industry clusters within the city to facilitate the exchange of tacit and explicit knowledge flows." These industry clusters are discussed mainly in line with the industry's contribution to the economy. The finance sector is the primary industry, accounting for $43 \%$ of the city economy in 2013 . It is not surprising to find that a significant customer of AI applications is the finance sector.

In contrast to Sydney, the Berlin government does not seem to have a focused industry approach. While Fintech is emerging in Berlin, there is no overall industry focus to the same extent in policy documents as in Sydney.

Sydney's technology-based EE is evolving successfully in a domestic context, but in international comparison, it is challenged by a lack of competitive culture and critical mass [S4]. Berlin was lucky to have had early success, which resulted in reaching this critical mass. It is also important to acknowledge the crucial role of the city's attractiveness and tolerant culture for this organic growth (B2). In a similar vein, the Digital Economy document (BD2) reports that "Berlin is versatile, vibrant, international. English is spoken in companies, used for the global market, and develops global thinking."

Even though reaching a critical mass is one of the critical challenges, according to the interviewees in Sydney, government documents (SD1 and SD3) emphasise the knowledge spillover problem. These documents want to support localised cluster development by enhancing connectivity and collaboration and spatial facilitation of innovation. In a way, policymakers are aware of the importance of knowledge spillovers. Perhaps this has influenced how the Technology Start-up Plan encourages building space where entrepreneurs could meet and interact (SD1). Sydney's local government responded to this advice by opening the largest entrepreneurship accelerator in Australia in 2017, the Sydney Startup $\mathrm{Hub}$, located at the centre of the business district with a capacity of 2500 people.

In line with our previous findings, the knowledge spillover problem is pointed out as a significant hindrance. B2 and B4 refer to the existence of silos between academia and startups. At the same time, BD3 points to connecting startups and industry as a strategic priority and the need for facilitating knowledge transfer to small and medium enterprises.

The success of startups depends not only on the local government, but also on the collaborative environment with big companies operating in the local context. While in Sydney, these connections are working (specifically for Fintech), the focus on tech activities' remains with the big companies. In Berlin, however, there used to be a historical culture of 
disrupting business, rather than collaborating with existing incumbent firms or government customers. However, Berlin startups seem to be slowly changing their attitudes towards a more collaborative culture (B3).

Two significant sources have been mentioned in government documents in both cities: money and data. Even though funding opportunities have been critical for startups, it seems their role has been perceived much more critical for Sydney's EE. Berlin interviewees (B2 and B3) consider that the city's attractiveness comes from other city benefits. This is also mentioned in BD2: "The endless leisure activities, good food, cultural diversity and people from around the world bring together lifestyle and work like no place else." Even though Berlin is the European leader in VC investments, the value is still nine times less than what Silicon Valley attracts (BD1).

Regarding the data availability, government documents from both cities indicate how the government could collect and share data at the city level and, by doing so, support the development of technology startups and foster a digital economy. SD2 considers government involvement in activities associated with city data collection, management, use, and release as critical support for Sydney's digital economy. SD1 argues specifically that "Tech startups have the most significant impact on information-centric industries, which tend to cluster in big cities. These industries include financial services, advertising, marketing services, publishing, entertainment, real estate, and design. Sydney is no exception."

Sydney policymakers are aware of the role of the quality of life (SD3). They complain about the increasing costs of living and doing business in Sydney. Coupled with poor transportation and infrastructure, this is seen as a worrying trend and significant challenge. S1 and S2 consider that Sydney beaches and lifestyle have been an attraction for people. However, it has been disadvantageous for business due to the perception that people in Sydney do not work hard but instead relax at the beach. In contrast, Berlin policymakers are proud of their city's attractiveness for talent and business. In BD2 the global attractiveness of the city is shown as the main reason for the establishment of R\&D centres in Berlin by global leaders like SAP, Cisco, and Amazon.

\section{Discussion}

This paper explores the interrelationship between AI practices concerning policies and the AI knowledge bases in Berlin's and Sydney's EEs over time. We use a triangulation of diverse data sets collected for Berlin and Sydney to examine the dynamics of policies and three knowledge bases: emerging, realising, and experimental. By following the knowledgespillover theory of entrepreneurship, we highlight the urgent need for a proactive urban strategy to help knowledge spillovers for a well-defined set of strategic purposes such as innovation and competitiveness at a macro level [24]. This proactive strategy is highly customised by local authorities and EE actors and applied at the macro-level for the given geographical jurisdictions.

Comparing practices taking place in two different EEs brings forward the critical role of context in EEs. Even though international entrepreneurial indexes point out higher rankings for Australia than Germany, city level comparisons for the specific sub-unit of an EE around AI show that Berlin outperforms Sydney. However, more importantly, the comparisons show the role of context at play. First, the existence of an emerging knowledge base does not guarantee a commercialisation activity in a region. In other words, emerging knowledge does not necessarily turn into realised or experimental knowledge. This problem has been widely shown in the extant literature of the knowledge-spillover theory of entrepreneurship. However, a discussion of the local content of the emerging knowledge seems to be neglected. In Berlin, the origins of emerging knowledge rely more on local sources than Sydney. Nevertheless, emerging knowledge has somewhat found its way to startups even though Berlin's local realised knowledge base (i.e., patents) has not been strong. In Sydney's case, the weak realised knowledge base and the comparatively 
internationalised emerging knowledge base have resulted in insufficient experimental knowledge.

Second, policymakers in these two cities are highly interested in economic growth through innovation and digital technologies. However, their policies mainly target the experimental knowledge base. Both cities' policymakers care about universities and support their role as homes for startups at university campuses, but they do not offer policies regarding knowledge spillovers. This negligence is particularly critical for Sydney, since the reliance on external actors in developing emerging knowledge seems to generate a critical hindrance in the knowledge spillover. Policymakers should realise their role in all forms of knowledge bases to facilitate spillovers among these different forms.

Third, the Berlin and Sydney cases show that practices related to knowledge bases and policy influence each other. It seems these interactions explain why experimental knowledge in Berlin has reached a critical mass with different sizes of startups compared to Sydney. Policy documents and interviews indicate how a smart city agenda and a complementary resource offering shape EE practices. Sydney policymakers have adopted a top-down approach policy and become a significant enabler for startups in addition to the finance sector, the largest sector in Sydney. In contrast, Berlin policymakers have allowed a bottom-approach and prioritised attracting talent and large companies to Berlin.

\subsection{Implications for Theory}

Our findings contribute to the entrepreneurship literature in several ways. First, we add knowledge to the understanding of EE dynamics in geographically bounded regions. As shown in the analysis of the small and knowledge-intensive sub-system of AI in Berlin and Sydney, the practices evolve differently for emerging, realised, and experimental knowledge bases. These nuanced discussions on knowledge bases allow us to compare two cities empirically. Thus, our paper's research framework could be applicable to other cities to shed light on the interactions between policies and knowledge bases. Second, we compare the dynamics of knowledge-based EEs in two cities by including the narratives of EEs at the policy level as popularised in recent work [50]. Our study highlights how observations from policy documents point out the gaps in integrating policies and strategies. Third, our findings present empirical data supporting studies emphasising the importance of the local dimension in entrepreneurship [8]. Finally, using the lens of the knowledgespillover theory of entrepreneurship allows to observe how the existence of local industries plays a key role in utilising emerging knowledge and turning it into realised knowledge, encouraging opportunities for experimental knowledge.

\subsection{Implications for Practice}

Our paper offers a practice-based approach to study knowledge-intensive EEs. There are two significant implications for practice. First, actors involved in AI knowledge bases need to find ways of overcoming barriers to spillovers. Second, policymakers should be aware of the role of specialised and integrated policies in determining a city's overall success in building EEs. We argue that policymakers need to integrate a diverse set of economic, technological, and entrepreneurial policies to establish a successful EE around AI. The key seems to be building a knowledge system where spillovers occur among different actors, universities, companies, startups, and government organisations. A focused and integrated effort around AI knowledge bases nurtures the whole ecosystem, e.g., university courses can be designed around the focal theme, providing custom-tailored graduates for local employers in industry and academia.

Interestingly, both cities have not referred to their existing technological capacities. In Berlin's case, this shortcoming does not seem to impact the dynamics of knowledge bases since its technological capacities are mainly local. However, in Sydney, policymakers have missed detecting the city's overreliance on external partners and funds for generating emerging knowledge over the years. A better understanding of the dynamics of citylevel knowledge bases and potentials could be a crucial building block to align economic, 
entrepreneurial, and technology strategies. This assumption is based on the concept of technological relatedness, whereby new and even disruptive industries build on existing local technological knowledge bases [69]. Therefore, our suggestion is first to identify the city's technological capacities to supply critical information such as the city's technological strengths, the evolution of the city's technological base over time, and key actors in each technology field. Building on the identified technological strengths, entrepreneurial and technology strategy can be aligned in a second step and a roadmap towards a successful AI-EE can be developed.

\section{Conclusions}

This paper responds to the calls for exploring the role of context for EEs [4,11]. By drawing on the knowledge-spillover theory of entrepreneurship, we studied two cities practices around AI knowledge bases and EE-related policies and highlighted the critical role of local environment.

In particular, we highlight the need for a proactive urban strategy to help knowledge spillovers for a well-defined set of strategic purposes such as innovation and competitiveness at a macro level [24]. This proactive strategy is highly customised by local authorities and EE actors and applied at the macro-level for the given geographical jurisdictions, respectively Berlin and Sydney. Furthermore, we encourage policy makers and entrepreneurs to rethink the city-level strategies in relation to knowledge spillovers. The findings highlight that cities can utilise their local knowledge, ranging from emerging and realised to experimental, in local markets effectively only if they succeed in integrating their policies at the macro level.

Some limitations should be mentioned regarding this research study, which might create future opportunities for researchers. First, we did not include the views of all types of actors belonging to an EE. For the sake of providing first exploratory insights on an ecosystem level in relation to impacts on policy making, we did not interview venture capitalists or individual entrepreneurs in our study. Future studies might expand the investigation to consider the visions and practices in delivering financial capital as well as a number of individual experiences of entrepreneurs. Second, we conducted four interviews in both cities. The main focus was on the policy documents, but we wanted to validate our readings of these documents with people involved in the process. Researchers might broaden the investigation of the EE narratives by including more diverse sets of documents representing many features of EE, such as the finance and education sectors. Third, our study is based on proxy metrics for the assessment of three knowledge bases. There are different ways to gather those data, and more consideration can be given to distinguishing between codified and tacit elements of knowledge bases [39]. By including our exploratory interviews, we have attempted to access those more tacit elements of knowledge through face-to-face interactions. Finally, the study compares two cities from two advanced economies. It could be an interesting research topic to explore cities from developing countries and apply our paper's research design. Once we have further empirical evidence, we will be in a situation to propose a theoretical framework to advance the knowledge-spillover theory of entrepreneurship to understand EEs.

Author Contributions: Data curation, T.L. and M.B.; Formal analysis, T.L. and D.C.; Investigation, T.L. and M.B.; Methodology, D.C.; Project administration, T.L.; Writing—original draft, T.L. and D.C.; Writing-review \& editing, T.L., D.C. and M.B. All authors have read and agreed to the published version of the manuscript.

Funding: This article was supported by an internal grant to strengthen the collaboration between the partner universities University of Technology Sydney and Technical University Berlin.

Institutional Review Board Statement: The study was conducted according to the guidelines of the Declaration of Helsinki, and approved by the Ethics Committee of University of Technology Sydney.

Informed Consent Statement: Informed consent was obtained from all subjects involved. 
Data Availability Statement: Except interviews, all data is publically available as given in the references.

Acknowledgments: The authors want to thank to all the experts that participated in the research process and the reviewers for their constructive feedback on the previous version of the paper.

Conflicts of Interest: The authors declare no conflict of interest.

\section{References}

1. Stam, E. Entrepreneurial ecosystems and regional policy: A sympathetic critique. Eur. Plan. Stud. 2015, 23, 1759-1769. [CrossRef]

2. Aarikka-Stenroos, L.; Rittala, P. Network management in the era of ecosystems: Systematic review andmanagement framework. Ind. Mark. Manag. 2017, 67, 23-36. [CrossRef]

3. van der Borgh, M.; Cloodt, M.; Romme, A.G.L. Value creation by knowledge-based ecosystems: Evidence from a field study. RD Manag. 2012, 42, 150-169.

4. Cetindamar, D.; Lammers, T.; Sick, N. Understanding the Relationship Between Smart Cities and Entrepreneurial Ecosystems: The Case of Sydney. In Data-Driven Multivalence in the Built Environment, S.M.A.R.T. Environments; Springer: Cham, Switzerland, 2019; pp. 301-315.

5. Zahra, S.A.; Wright, M.; Abdelgawad, S.G. Contextualization and the advancement of entrepreneurship research. Int. Small Bus. J. 2014, 32, 479-500. [CrossRef]

6. Watson, T.J. Entrepreneurship in action: Bringing together the individual, organizational and institutional dimensions of entrepreneurial action. Entrep. Reg. Dev. 2013, 25, 404-422. [CrossRef]

7. Autio, E.; Nambisan, S.; Thomas, L.; Wright, M. Digital affordances, spatial affordances, and the genesis of entrepreneurial ecosystems. Strat. Entrep. J. 2017, 12, 72-95. [CrossRef]

8. Acs, Z.J.; Szerb, L.; Lloyd, A. Global Entrepreneurship and Development Index 2017; CreateSpace Independent Publishing Platform: Washington, DC, USA, 2017.

9. Qian, H. Knowledge base differentiation in urban systems of innovation and entrepreneurship. Urban Stud. 2018, 54, 1655-1672. [CrossRef]

10. Acs, Z.J.; Braunerhjelm, P.; Audretsch, D.B.; Carlsson, B. The knowledge spillover theory of entrepreneurship. Small Bus. Econ. 2009, 32, 15-30. [CrossRef]

11. Thompson, N.N.; Verduijn, K.; Gartner, W.B. Entrepreneurship-as-practice: Grounding contemporary theories of practice into entrepreneurship studies. Entrep. Reg. Dev. 2020, 32, 247-256. [CrossRef]

12. Qian, H.; Jung, H. Solving the knowledge filter puzzle: Absorptive capacity, entrepreneurship and regional development. Small Bus. Econ. 2017, 48, 99-114. [CrossRef]

13. Spigel, B. The relational organization of entrepreneurial ecosystems. Entrep. Theory Pract. 2017, 41, 49-72. [CrossRef]

14. Cavallo, A.; Ghezzi, A.; Balocco, R. Entrepreneurial ecosystem research: Present debates and future directions. Int. Entrep. Manag. J. 2019, 15, 1291-1321. [CrossRef]

15. Kaplan, A.; Haenlein, M. Siri, Siri, in my hand: Who's the fairest in the land? On the interpretations, illustrations, and implications of artificial intelligence. Bus. Horiz. 2019, 62, 15-25. [CrossRef]

16. Groopman, J.; Lieb, R.; Owyang, J.; Syzmanski, J. Three Macrotrends Impacting the Journey to 2030; Kaleido Insights: San Francisco, CA, USA, 2017.

17. Chalmers, D.; MacKenzie, N.G.; Carter, S. Artificial intelligence and entrepreneurship: Implications for venture creation in the fourth industrial revolution. Entrep. Theory Pract. 2021, 45, 1028-1053. [CrossRef]

18. Cetindamar, D.; Lammers, T.; Zhang, Y. Exploring the knowledge spillovers of a technology in an entrepreneurial ecosystem-The case of artificial intelligence in Sydney. Thunderbird Int. Bus. Rev. 2020, 62, 457-474. [CrossRef]

19. Spigel, B.; Harrison, R. Toward a process theory of entrepreneurial ecosystems. Strateg. Entrep. J. 2018, 12, 151-168. [CrossRef]

20. Malerba, F.; McKelvey, M. Knowledge-intensive innovative entrepreneurship integrating Schumpeter, evolutionary economics, and innovation systems. Small Bus. Econ. 2020, 54, 503-522. [CrossRef]

21. Taalbi, J. Evolution and structure of technological systems-An innovation output network. Res. Policy 2020, 49, 8. [CrossRef]

22. Audretsch, D.B.; Belitski, M.; Caiazza, R.; Lehmann, E.E. Knowledge management and entrepreneurship. Int. Entrep. Manag. J. 2020, 16, 373-385. [CrossRef]

23. Audretsch, D.B.; Keilbach, M. The theory of knowledge spillover entrepreneurship. J. Manag. Stud. 2007, 44, 1242-1254. [CrossRef]

24. Ferreira, J.J.; Ratten, V.; Dana, L.-P. Knowledge spillover-based strategic entrepreneurship. Int. Entrep. Manag. J. 2017, 13, 161-167. [CrossRef]

25. Ascani, A.; Bettarelli, L.; Resmini, L.; Balland, P.-A. Global networks, local specialisation and regional patterns of innovation. Res. Policy 2020, 49, 104031. [CrossRef]

26. Balland, P.-A.; Boschma, R.; Frenken, K. Proximity and innovation: From statics to dynamics. Reg. Stud. 2014, 49, 907-920. [CrossRef]

27. Audretsch, D.B.; Belitski, M. Entrepreneurial ecosystems in cities: Establishing the framework conditions. J. Technol. Transf. 2016, 42, 1030-1051. [CrossRef] 
28. Fischer, B.; Queiroz, S.; Vonortas, N. On the location of knowledge-intensive entrepreneurship in developing countries: Lessons from São Paulo, Brazil. Entrep. Reg. Dev. 2018, 30, 612-638. [CrossRef]

29. Miller, D.J.; Acs, Z.J. The campus as entrepreneurial ecosystem: The University of Chicago. Small Bus. Econ. 2017, 49, 75-95. [CrossRef]

30. Sussan, F.; Acs, Z.J. The digital entrepreneurial ecosystem. Small Bus. Econ. 2017, 49, 55-73. [CrossRef]

31. Startup Genome. Global Startup Ecosystem Report; Startup Genome: Berlin, Germany, 2012. Available online: https: / / startupgenome.com/reports/global-startup-ecosystem-report-2012 (accessed on 16 June 2020).

32. Startup Genome. Global Startup Ecosystem Report; Startup Genome: Berlin, Germany, 2019. Available online: https: / / startupgenome.com/report/gser2019 (accessed on 16 June 2020).

33. GEDI. GEI 2006-2016 Dataset; The Global Entrepeneurship and Development Institute: Washington, DC, USA, 2017.

34. Acs, Z.J.; Szerb, L.; Lafuente, E.; Markus, G. Global Entrepreneurship Index; The Global Entrepreneurship and Development Institute: Washington, DC, USA, 2019.

35. Akter, S.; Bandara, R.; Hani, U.; Wamba, S.F.; Foropon, C.; Papadopoulos, T. Analytics-based decision-making for service systems: A qualitative study and agenda for future research. Int. J. Inf. Manag. 2019, 48, 85-95. [CrossRef]

36. Silverman, D. Interpreting Qualitative Data: A Guide to the Principles of Qualitative Research, 4th ed.; Sage: Londong, UK, 2011.

37. Adomavicius, G.; Bockstedt, J.; Gupta, A.; Kauffman, R. Making sense of technology trends in the information technology landscape: A design science approach. MIS Q. 2008, 32, 779-809. [CrossRef]

38. Motohashi, K. Understanding AI Driven Innovation by Linked Database of Scientific Articles and Patents; Research Institute of Economy, Trade and Industry [RIETI]: Tokyo, Japan, 2018.

39. Qian, H. Knowledge-based regional economic development: A synthetic review of knowledge spillovers, entrepreneurship and entrepreneurial ecosystems. Econ. Dev. Q. 2018, 32, 163-176. [CrossRef]

40. Jha, S.K. Creating experiential knowledge networks in emerging entrepreneurial ecosystems. Acad. Manag. Annu. Meet. Proc. 2016, 2016, 1. [CrossRef]

41. Lindholm-Dahlstrand, A.; Andersson, M.; Carlsson, B. Entrepreneurial experimentation: A key function in systems of innovation. Small Bus. Econ. 2019, 53, 591-610. [CrossRef]

42. Li, K.; Rollins, J.; Yan, E. Web of Science use in published research and review papers 1997-2017: A selective, dynamic, crossdomain, content-based analysis. Scientometrics 2018, 115, 1-20. [CrossRef] [PubMed]

43. Leydesdorff, L.; Carley, S.; Rafols, I. Global maps of science based on the new Web-of-Science categories. Scientometrics 2013, 94, 589-593. [CrossRef]

44. Gao, F.; Jia, X.; Zhao, Z.; Chen, C.-C.; Xu, F.; Geng, Z.; Song, X. Bibliometric analysis on tendency and topics of artificial intelligence over last decade. Microsyst. Technol. 2019, 27, 1545-1557. [CrossRef]

45. WIPO. The free global search engine for technology information. In Patentscope; World Intellectual Property Organization: Geneva, Switzerland, 2017.

46. WIPO. PATENTSCOPE Artificial Intelligence Index. 2019. Available online: https://www.wipo.int/tech_trends/en/artificial_ intelligence/patentscope.html (accessed on 8 July 2020).

47. WIPO. Background paper on data collection method and clustering scheme. In Technology Trends 2019 Artifficial Intelligence; World Intellectual Property Organization: Geneva, Switzerland, 2019.

48. Dalle, J.M.; den Besten, M.; Menon, C. Using Crunchbase for Economic and Managerial Research; OECD Publishing: Paris, France, 2017.

49. Crunchbase. AI Startups 2020. Available online: https://www.crunchbase.com/search/organizations/field/hubs/org_num/ artificial-intelligence-startups (accessed on 8 July 2020).

50. Borrás, S.; Edler, J. The roles of the state in the governance of socio-technical systems' transformation. Res. Policy 2020, $49,103971$. [CrossRef]

51. Mitze, T.; Strotebeck, F. Determining factors of interregional research collaboration in Germany's biotech network: Capacity, proximity, policy? Technovation 2019, 80-81, 40-53. [CrossRef]

52. Etikan, I.; Musa, S.A.; Alkassim, R.S. Comparison of convenience sampling and purposive sampling. Am. J. Theor. Appl. Stat. 2016, 5, 1-4. [CrossRef]

53. Fereday, J.; Muir-Cochrane, E. Demonstrating rigor using thematic analysis: A hybrid approach of inductive and deductive coding and theme development. Int. J. Qual. Methods 2006, 5, 80-92. [CrossRef]

54. Bowen, G.A. Document analysis as a qualitative research method. Qual. Res. J. 2009, 9, 27-40. [CrossRef]

55. Berliner Agenda für ein Optimiertes Gründungsumfeld 2016. Berlin: City of Berlin. Available online: https://www.berlin.de/ rbmskzl/aktuelles/pressemitteilungen/2016/pressemitteilung.466549.php (accessed on 16 July 2020).

56. Digital Economy in Berlin. Berlin: City of Berlin-Berlin Partner 2016. Available online: http://webkiosk.berlin-partner.de/ digital-economy-in-berlin/55632576/10 (accessed on 16 July 2020).

57. Industriestadt Berlin Masterplan 2018-2021; City of Berlin—Senate Department for Economics, Energy and Public Enterprises: Berlin, Germany, 2018; Available online: https:/ /www.berlin.de/industriestadt/masterplan-industriestadt-berlin-2018-2021/ (accessed on 16 July 2020).

58. Sydney. Tech Startups Action Plan. 2016. Available online: https://www.cityofsydney.nsw.gov.au/strategies-action-plans/techstartups-action-plan (accessed on 3 April 2018). 
59. Sydney. Digital Strategy. 2018. Available online: https://www.cityofsydney.nsw.gov.au/strategies-action-plans/digital-strategy (accessed on 3 April 2018).

60. Sydney. Economic Development Strategy. 2013. Available online: https://www.cityofsydney.nsw.gov.au/strategies-actionplans/economic-development-strategy (accessed on 16 July 2020).

61. Yin, R.K. Case Study Research And Applications: Design and Methods; Sage: Los Angeles, CA, USA, 2017.

62. Blumberg, B.; Cooper, D.R.; Schindler, P.S. Business Research Methods, 2nd ed.; McGraw-Hill: London, UK, 2008.

63. Cresswell, J.W.; Plano Clark, V.L. Designing and Conducting Mixed Method Research, 2nd ed.; Sage: Thousand Oaks, CA, USA, 2011.

64. Castro, A. Are you talking to me? The Economist Technology Quarterly. 2007. Available online: https://www.economist.com/ technology-quarterly/2007/06/09/are-you-talking-to-me (accessed on 12 June 2020).

65. Markoff, J. Behind artificial intelligence, a squadron of bright real people. New York Times. 14 October 2005. Available online: https: / / www.nytimes.com/2005/10/14/technology/behind-artificial-intelligence-a-squadron-of-bright-real-people.html (accessed on 25 September 2020).

66. Lowe, N.J.; Feldmann, M.P. Institutional life within an entrepreneurial region. Geogr. Compass 2017, 11, 1-10. [CrossRef]

67. Munoz, P.; Kibler, E.; Mandakovic, V.; Amoros, J. Local entrepreneurial ecosystems as configural narratives: A new way of seeing and evaluating antecedents and outcomes. Res. Policy 2020. [CrossRef]

68. Cetindamar, D.; Gunsel, A. Measuring the Creativity of a City: A Proposal and an Application. Eur. Plan. Stud. 2012, 20, 1301-1318. [CrossRef]

69. Tannery, A.N. The emergence of new technology-based industries. J. Econ. Geogr. 2016, 16, 611-635. [CrossRef] 